\title{
First Record of a Yellow-bellied Sea Snake, Hydrophis platurus (Linnaeus 1766), from Gujarat, India
}

\author{
Dikansh S. Parmar
}

Department of Biosciences, Veer Narmad South Gujarat University, Surat, Gujarat, India (Ophiophagus_hannah10@yahoo.com)

$\mathrm{T}^{\mathrm{T}}$ he Yellow-bellied Sea Snake (Hydrophis platurus) is one of 13 species of sea snakes found along the coast of Gujarat State in India (Desai 2011, 2017). The Yellowbellied Sea Snake occurs in tropical oceanic waters except for the Atlantic Ocean (Whitaker and Captain 2008). In India, it occurs in nine coastal states and in the Andaman and Nicobar Islands (Fig. 1). Although these snakes have not been reported from the Lakshadweep Islands, they are likely to occur there as well since they are known from the Kerala coast (Palot and Radhakrishnan 2010; Palot 2015) and the Maldives (Whitaker and Captain 2008; Project Maldives 2015).

At 1700 h on 6 July 2010, while I was conducting fieldwork in the area, a fisherman from Magdalla Village, Surat District, in southern Gujarat, brought me a snake he had caught. I identified it as a Yellow-bellied Sea Snake (Hydrophis platurus; Fig. 2), the first record of this species in the state of Gujarat. The maximum length reported for $H$. platurus is $980 \mathrm{~mm}$ (Whitaker and Captain 2008), indicating that this male (SVL $269.1 \mathrm{~mm}$, tail $38.2 \mathrm{~mm}$ ) was a juvenile. Midbody scale rows numbered 61 and ventrals 312 . The color was unusual (Fig. 2) and best characterized as albinotic (a tendency toward albinism with variable quantities of pigment present). Instead of a black or dark brown dorsum and bright yellow flanks and venter, the anterior third of the dorsum was light brown in color and the posterior two-thirds were light grayish-brown. The sides and venter were pale yellow anteriorly to pale cream posteriorly, including the ground color on the tail. The normally black bands or bars on the tail were gray. Even the iris, which Whitaker and Captain (2008) described as black, was a grayish yellow.

Sea snakes in general are vulnerable to getting caught in fishing nets, but most fishermen in this region release snakes rather than killing them; consequently fishing is not a major threat to sea snakes in the Surat District. However, marine life along the Surat coast is seriously threatened and rapidly vanishing due to pollution generated by major coastal industries. In a

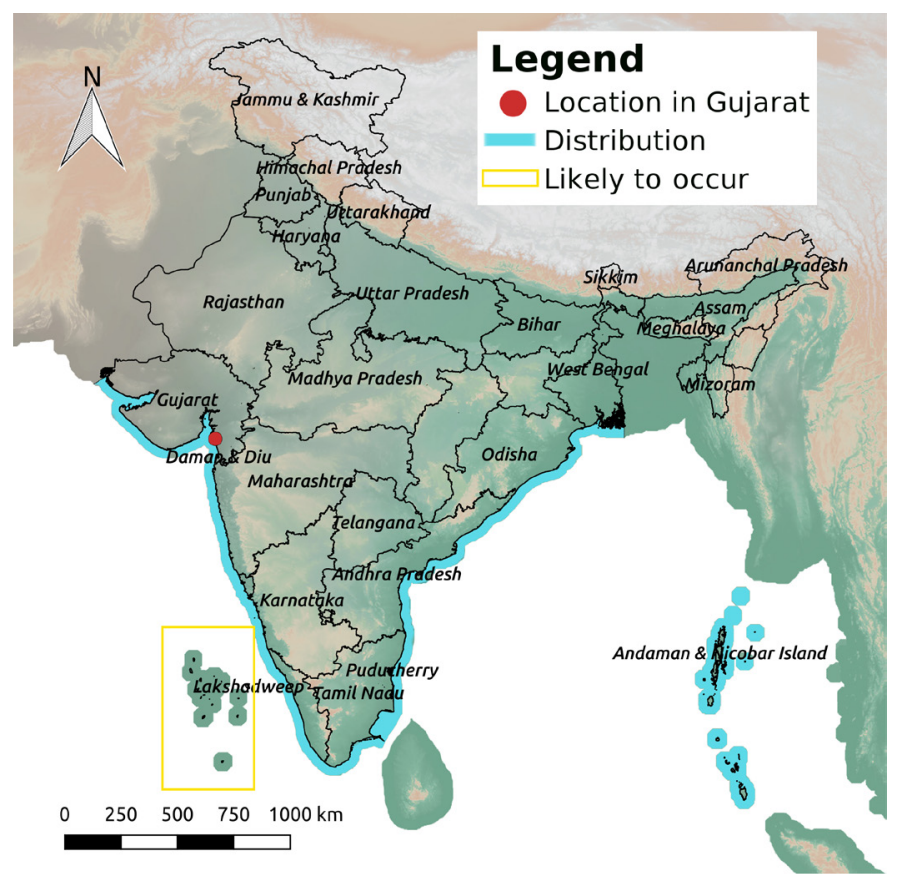

Fig 1. The distribution of the Yellow-bellied Sea Snake (Hydrophis platurus) in India showing the new locality near Magdalla, Surat District, Gujarat.

survey on marine biology in 2011, I interviewed native fishermen who stated that large amounts of toxic wastes had been released into estuaries in recent years and that dead fish floating on the surface were ubiquitous. They also reported that no appropriate actions had been taken although many officials had visited the site. They indicated that toxic wastes has drastically reduced local populations of sharks, other fishes, and sea snakes, and that survivors are forced to migrate to less polluted sites.

\section{Acknowledgement}

I thank Jenis R. Patel of the Nature Conservation Foundation, Bengaluru, Karnataka, for creating the map. 

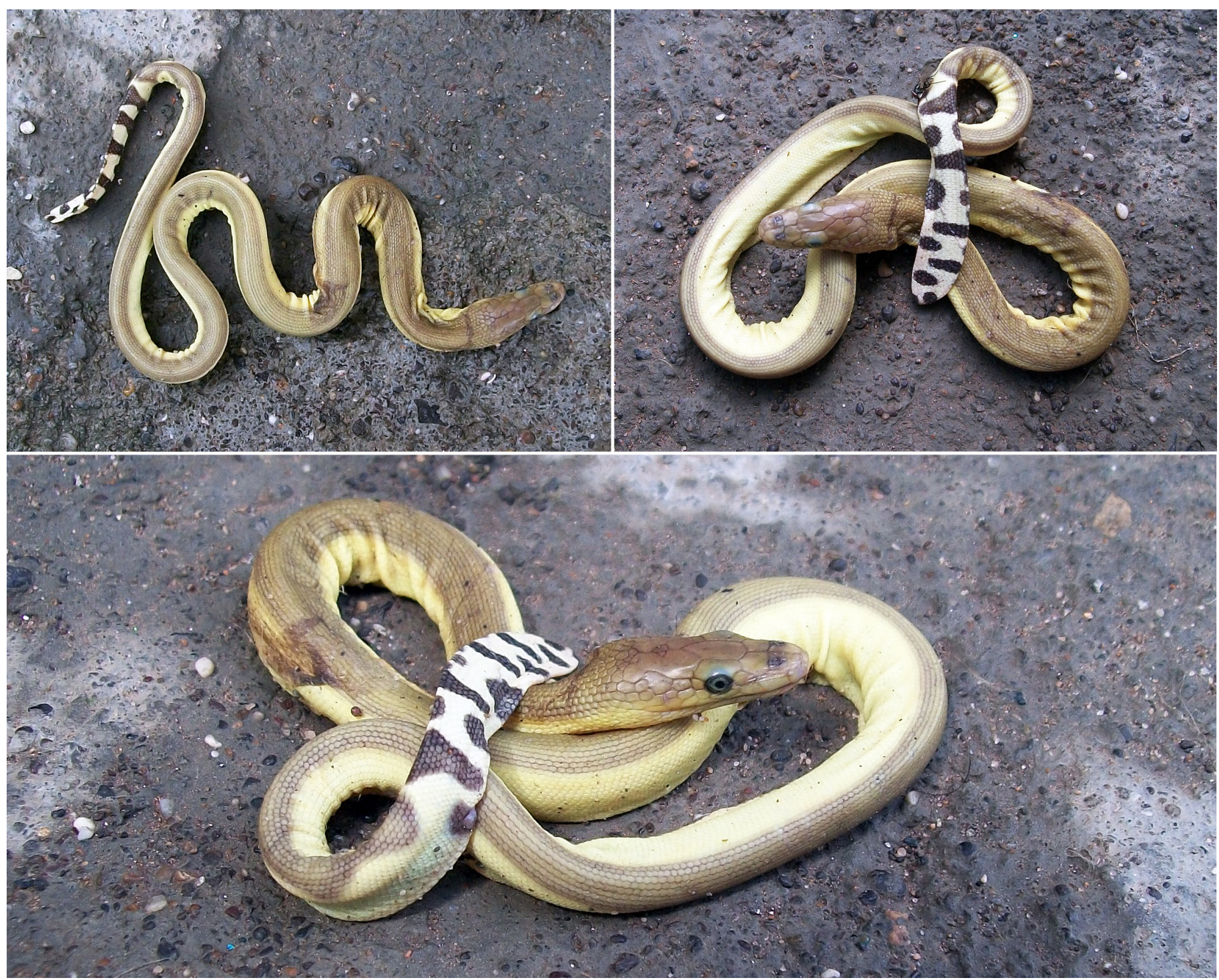

Fig. 2. A juvenile albinotic Yellow-bellied Sea Snake (Hydrophis platurus) from Magdalla, Surat District, Gujarat, India. Photographs by Dikansh S. Parmar.

\section{Literature Cited}

Desai, A. 2011. Sarp Sandarbh: The Snakes of Gujarat. Prakrutri Mitra Mandal, Dahod, Gujarat, India.

Desai, A. 2017. Sarp Sandarbh: The Snakes of Gujarat. Prakrutri Mitra Mandal, Dahod, Gujarat, India.

Project Maldives. 2015. Herpetofauna (https://projectmaldives2015.wordpress. $\mathrm{com} /$ species-list/herpetofauana/).
Palot, M.J. 2015. A checklist of reptiles of Kerala, India. Journal of Threatened Taxa 7: 8010-8022.

Palot, M.J. and C. Radhakrishnan. 2010. First record of Yellow-bellied Sea Snake Pelamis platurus (Linnaeus, 1766) (Reptilia: Hydrophiidae) from a riverine tract in northern Kerala, India. Journal of Threatened Taxa 2: 1175-1176.

Whitaker, R. and A. Captain. 2008. Snakes of India: The Field Guide. Draco Books, Chennai, India. 